\title{
Їнтеграція програм фізичної реабілітації в процес першого-третього етапів підготовки спортсменів при дисфункціях систем їх організму
}

\author{
УДК 796.015.3:616-008:615.825.001.12
}

\section{В. О. Кашуба ${ }^{1}$, С. С. Люгайло ${ }^{2}$, С. М. Футорний 1}

${ }^{1}$ Національний університет фізичного виховання і спорту України, Київ, Україна

2 Український медичний центр спортивної медицини МОЗ України, Київ, Україна

Резюме. Мета. Виходячи з особливостей функціонального стану юних спортсменів сформувати методичні рекомендації щодо раціональної інтеграції засобів і методів фізичної реабілітації (ФР) в програми підготовки на першому-третьому етапах. Матеріал і методи. У педагогічному експерименті взяли участь 260 спортсменів віком 9-17 років (футбол: хлопчики, юнаки - 162 особи; волейбол: дівчатка, дівчата - 98 осіб). Використовували комплекс діагностичних методів - скринінг функціонального стану спортсменів (п'ять етапів). Результати. Обґрунтовано та розроблено організаційно-методичні основи процесу ФР при дисфункціях систем організму спортсменів у процесі першого-третього етапів багаторічної підготовки. Удосконалено мету, завдання, принципи реалізації процесу ФР в практиці початкових етапів підготовки - технологія інтеграції. Запропоновано методичне забезпечення процесу інтеграції, який принципово відрізняється наявністю діагностичного компонента для подальшого вдосконалення здоров'яформуючої складової спортивної підготовки. Висновки. Результати педагогічного дослідження підтвердили ефективність розробленої технології, що свідчить про доцільність запропонованих методичних рекомендацій.

Ключові слова: фізична реабілітація, технологія інтеграції, юні спортсмени, багаторічна підготовка, функціональні системи.

\section{Интеграция программ физической реабилитации в процесс первого-третьего этапов подготовки при дисфункциях соматических систем \\ В. А. Кашуба', С. С. Люгайло', С. М. Футорный ${ }^{1}$}

\footnotetext{
1 Национальный университет физического воспитания и спорта Украины, Киев, Украина

2 Украинский медицинский центр спортивной медицины МОЗ Украины, Киев, Украина
}

Резюме. Цель. Исходя из особенностей функционального сотояния юных спортсменов сформировать методические рекомендации по рациональной интеграции средств и методов физической реабилитации (ФР) в программы подготовки на первом-третьем этапах. Материалы и методы. В педагогическом эксперименте участвовали 260 спортсменов 9-17 лет (футбол: мальчики, юноши - 162 человека; волейбол: девочки, девушки 98 человек). Использовали комплекс диагностических методов - поуровневая скрининг функционального состояния спортсменов (пять этапов). Результаты. Обоснованы и разработаны организационно-методические основы процесса ФР при дисфункциях систем организма спортсменов в процессе первого-третьего этапов многолетней подготовки. Усовершенствованы цели, задачи, принципы реализации процесса ФР в практике начальных этапов подготовки - технология интеграции. Предложено методическое обеспечение процесса интеграции, который принципиально отличается наличием диагностического компонента для дальнейшего совершенствования здоровьеформирующей составляющей спортивной подготовки. Вывод. Результаты исследования подвердили эффективность разработаной технологии, что свидетельствует о целесообразности предложенных методических рекомендаций.

Ключевые слова: физическая реабилитация, технология интеграции, юные спортсмены, многолетняя подготовка, функциональные системы. 


\title{
Integration of physical rehabilitation programs in the process of the first - third stages of training of athletes during dysfunctions of their body systems
}

\section{O. Kashuba ${ }^{1}$, S. S. Liuhaylo ${ }^{2}$, S. M. Futornyi ${ }^{1}$}

${ }^{1}$ National University of Physical Education and Sport of Ukraine, Kyiv, Ukraine

${ }^{2}$ Ukrainian Medical Centre of Sports Medicine of the MPH of Ukraine, Kyiv, Ukraine

\begin{abstract}
Objective. To make methodological recommendations for the rational integration of physical rehabilitation (FR) methods and means in the training programs at the first-third stages based on the peculiarities of the functional status of young athletes. Material and methods. 260 athletes aged 9-17 participated in the pedagogical experiment (football: boys, adolescents 162 persons; volleyball: girls, girls - 98 persons. A set of diagnostic methods - screening of the functional state of athletes (five stages) was used. Results. The organizational and methodological foundations of the FR process during body system dysfunctions in athletes in the process of the first-third stages of long-term preparation have been substantiated and developed. The goal, tasks, principles of implementation of the FR process in the practice of the initial stages of preparation - technology of integration have been improved. Methodological support of the integration process, which fundamentally differs by the presence of a diagnostic component for further improvement of the health-forming constituent of sports training, has been suggested. Conclusions. The results of the pedagogical study confirmed the effectiveness of the developed technology, which indicates the feasibility of the proposed methodological recommendations.
\end{abstract}

Keywords: physical rehabilitation, integration technology, young athletes, long-term preparation, functional systems.

Постановка проблеми. Пріоритет профрілактично-реабілітаційної складової процесу багаторічної підготовки спортсменів, обумовлений небезпечною ситуацією, що склалася зі здоров'ям юних атлетів протягом його першого-третього етапів [31, 32, 34]. На думку фрахівців, вона характеризується збільшенням числа негативних тенденцій у стані соматичного здоров'я атлетів на кожному з етапів становлення [13, 35, 38]. Доведено, що небезпечна динаміка обумовлена рядом чинників, котрі лімітують приріст рівня спортивної майстерності юних атлетів $[9,25,26]$ та перешкоджають розвитку системи олімпійської підготовки [39]:

- фрізіологічні особливості дитячого організму, які чітко виражені в критичні періоди онтогенезу $[6,11,36]$;

- педагогічні особливості етапів першої стадії спортивної підготовки, що пов'язані зі збільшенням основних параметрів навчально-тренувального процесу та початком активної змагальної діяльності спортсменів [3, 13, 32];

- недотримання принципів теорії періодизації, що сприяє розвитку патологій $[7,15,30]$;

- дисонанс між фуункціональними резервами організму, та фракторами тренувальної діяльності $[23,25,34]$;

- лімітуючий вплив прихованих та хронічних патологій на ефективність процесу професійного становлення молодих атлетів [8, 19, 21]. Ситуація ускладнюється різким зниженням кількості дітей, які мають «безпечний» рівень здоров'я [1, $23,37]$ та здатні тренуватися, витримуючи значні фрізичні навантаження, досягати високих спор- тивних результатів та у подальшому можуть бути залучені до спорту вищих досягнень [19, 26, 39]. Це підтверджено нами і поглиблено у ряді власних наукових публікацій $[18,28,29]$.

Систематизація зазначених чинників надала нам можливості для пояснення єдності мети профрілактичного та реабілітаційного компонентів здоров'язберігаючої складової етапів першої стадії багаторічної підготовки, яка стратегічно орієнтована на розширення адаптаційних резервів організму спортсменів та сприяння механізмам саногенезу [27], та визначила пріоритет педагогічних впливів у зазначених процесах, тобто стала передумовою для зміщення акцентів у сореру використання засобів і методів фрізичної реабілітації (ФР) (особливо на етапах дитячо-юнацького та резервного спорту) [18, 20]. Крім того, систематизація обгрунтувала вивчення об'єктивних умов практичного використання засобів ФР у сорері підготовки спортсменів віддаленого і найближчого резервів спорту вищих досягнень [29].

Результати вивчення фундаментальних знань, об'єднаних проблематикою дослідження, дозволили зробити висновок про неспроможність методологічних та організаційних умов використання фрізичних засобів та методів у практиці першого-третього етапів підготовки спортсменів з патологіями різних нозологічних груп [17]. Незважаючи на достатню кількість досліджень, на даний момент систематизовано лише незначну їх частину $[12,22,33]$. Встановлено, що накопичений матеріал характеризується однобічністю в аспектах нозологій, етапів підготовки спортсменів 
та рівнів реалізації процесу ФР $[4,5,10]$. Ситуація ускладнюється нерозумінням цілісності ФР як безперервного процесу профрілактичних, реабілітаційних, оздоровчих та здоров'яформуючих технологій, раціонально інтегрованих у програми підготовки спортсменів на правах рівноправного структурного компонента [20, 27].

Зазначені прорахунки спонукали нас до вивчення об'єктивних умов реалізації процесу ФР у практиці дитячо-юнацького спорту (методологічного, педагогічного, організаційного, медико-епідеміологічного та онтогенетичного характеру). Систематизація умов обгрунтувала теоретико-методичні основи концепції ФР при дисорункціях соматичних систем організму та їх донозологічних формах у юних спортсменів. Експериментальну ефективність концепції було неодноразово доведено шляхом реалізації технології інтеграції комплексних засобів і методів ФР у практику першого-третього етапів підготовки спортсменів [27].

Сукупність отриманих позитивних результатів спонукала нас до подальшої популяризації практичних напрацювань і презентації покрокових методичних рекомендацій щодо інтеграції засобів i методів ФР у програми підготовки спортсменів 3 дисфункціями систем їх організму та 3 їх передвісниками, що $є$ метою даної публікації.

Матеріал та методи дослідження. У педагогічному експерименті взяли участь 260 спортсменів віком 9-17 років, які спеціалізувалися в спортивних іграх (футбол: хлопчики, юнаки - 162 особи; волейбол: дівчатка, дівчата - 98 осіб) та тренувалися на першому-третьому етапах багаторічної підготовки. Зазначені етапи збігаються з віковими періодами: 9-11 років - початкової підготовки, 12-14 років - попередньої базової підготовки, 15-17 років - спеціалізованої базової підготовки, що відповідає навчальній програмі підготовки спортсменів даних спеціалізацій.

Організація дослідження. Дослідження проводилося на базі Національного університету фрізичного виховання і спорту України та в умовах тренувальної діяльності спортсменів-вихованців ДЮСШ з ігрових видів спорту, ДВУОР ім. С. Н. Бубки і спеціалізованої школи-інтернату. Медичні обстеження проводились в умовах обласного лікарсько-фрізкультурного диспансеру (м. Донецьк).

Технологія ФР, що пропонується, стратегічно орієнтована на етіологічно обгрунтовану фрункціональну корекцію ендогенних механізмів розвитку перед- та патологічних порушень у діяльності основних соматичних систем організму юних спортсменів. При застосуванні комплексного підходу до побудови стратегії і гнучкої
Спортивна медицина і фізична реабілітація, № 1, 2019

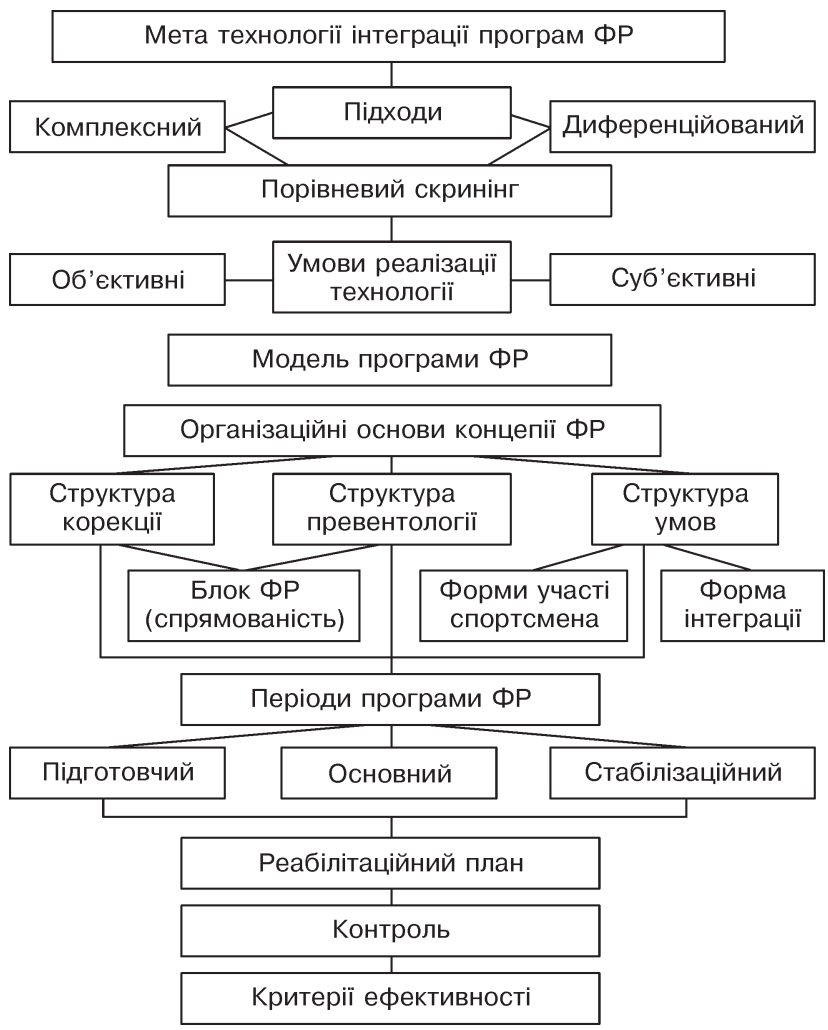

Рисунок 1 - Структура технології інтеграції спеціалізованих програм фізичної реабілітації в процес підготовки юних спортсменів

диференційованої корекції тактики процесу ФР використовували скринінг функціонального стану учасників процесу. Схема технології ФР представлена на рисунку 1.

Технологія ФР реалізується в умовах педагогічного експерименту. Ми пропонуємо чотири іï етапи.

На першому (початковому) етапі здійснюється планування реабілітаційної діяльності, виходячи з об'єктивних та суб'єктивних умов для її реалізації; обгрунтовується будова моделі стратегії процесу ФР спортсменів за кожним з його напрямів (превентивний, постнозологічний). Це $\epsilon$ компетенцією комплексної наукової групи (КНГ). До складу КНГ входять координатори діагностичної, методичної та практичної складових процесу ФР. Діагностична складова реалізується в умовах ЛФД. Фахівці з фрізичної реабілітації забезпечують методичну складову. Тренери-викладачі ДЮСШ, спортивні медики тренувальних баз, батьки спортсменів беруть участь у практичній реалізації.

Підгрунтям технології $\epsilon$ діагностичний скринінг соматичного здоров'я спортсменів. Його реалізація здійснюється на другому етапі. Скринінг містить доступні методи вивчення поточного 
ТАБЛИЦЯ 1 - Скринінг функціонального стану спортсменів

\begin{tabular}{|c|c|c|c|}
\hline Етап, метод дослідження & Оцінюваний параметр & Критерій оцінки & Результат (тактика реабілітаційних впливів) \\
\hline $\begin{array}{l}\text { Перший, поточне медич- } \\
\text { не обстеження }\end{array}$ & $\begin{array}{l}\text { Функціональний стан } \\
\text { спортсмена }\end{array}$ & $\begin{array}{l}\text { Здоровий; практично } \\
\text { здоровий; має відхилення } \\
\text { у стані здоров'я }\end{array}$ & $\begin{array}{l}\text { Тренувальна діяльність у повному обсязі; } \\
\text { корекція тренувального процесу з урахуван- } \\
\text { ням хронічних форм патології; обмеження } \\
\text { (часткове, повне) тренувальної діяльності }\end{array}$ \\
\hline $\begin{array}{l}\text { Другий, експрес-оцін- } \\
\text { ка рівня соматичного } \\
\text { здоров'я (Г. Л. Апана- } \\
\text { сенко) }\end{array}$ & $\begin{array}{l}\text { Іेндивідуальний рівень } \\
\text { соматичного здоров'я } \\
\text { спортсмена (IP3) }\end{array}$ & $\begin{array}{l}\text { Високий, вищий за се- } \\
\text { редній, середній, нижчий } \\
\text { за середній, низький }\end{array}$ & Здоровий; група ризику; хворий \\
\hline $\begin{array}{l}\text { Третій, оцінка пара- } \\
\text { метрів, що складають } \\
\text { показник IP3 }\end{array}$ & $\begin{array}{l}\text { Критерії функцій: } \\
\text { м'язової системи; фізич- } \\
\text { ного розвитку; зовніш- } \\
\text { нього дихання; резерву й } \\
\text { економізації ССС }\end{array}$ & $\begin{array}{l}\text { Високий, вищий за се- } \\
\text { редній, середній, нижчий } \\
\text { за середній, низький }\end{array}$ & $\begin{array}{l}\text { Не вимагають корекції засобами ФР; } \\
\text { підлягають впливу засобами й методами } \\
\text { загальнорозвиваючої та загальнооздоровчої } \\
\text { спрямованості; } \\
\text { підлягають корекційним впливам у трену- } \\
\text { вальних та позатренувальних блоках ФР }\end{array}$ \\
\hline $\begin{array}{l}\text { Четвертий, оцінка функ- } \\
\text { ціонального стану й } \\
\text { резервних можливостей } \\
\text { організму (С. А. Ду- } \\
\text { шанін, В. П. Карленко) }\end{array}$ & $\begin{array}{l}\text { Ступінь адаптації до фі- } \\
\text { зичного навантаження }\end{array}$ & $\begin{array}{l}\text { Задовільна адаптація; } \\
\text { напруження механізмів } \\
\text { адаптації; незадовільна } \\
\text { адаптація; зрив адаптації }\end{array}$ & $\begin{array}{l}\text { Тренувальна діяльність у повному обсязі; } \\
\text { корекція тренувального процесу до мо- } \\
\text { менту нормалізації функціонального стану; } \\
\text { відсторонення від тренувального процесу в } \\
\text { першому періоді програми ФР }\end{array}$ \\
\hline $\begin{array}{l}\text { П'ятий, комп'ютерне } \\
\text { тестування ФЗД (канал } \\
\text { «Спіро», «Кардіо+») }\end{array}$ & $\begin{array}{l}\text { Швидкісні та об’ємні } \\
\text { характеристики ФЗД } \\
\text { (бронхіальна прохідність) }\end{array}$ & $\begin{array}{l}\text { Зниження досліджуваних } \\
\text { характеристик (\%): легке; } \\
\text { помірне; значне; різке }\end{array}$ & $\begin{array}{l}\text { Корекція функціонального стану верхніх } \\
\text { відділів респіраторного тракту }\end{array}$ \\
\hline
\end{tabular}

функціонального стану спортсмена та параметрів його складових.

Першим етапом скринінгу є поточне медичне обстеження (ПМО) спортсменів основної групи [27]. Обсяг використовуваних методів: опитування, збір загального та спортивного анамнезів, антропометричні, фрункціональні й лабораторні методи, метод визначення реакції організму на фрізичне навантаження, огляд лікарів-фрахівців [7].

Результат - лікарський допуск спортсмена до тренувальної діяльності.

Другий етап скринінгу - експрес-оцінка індивідуального рівня соматичного здоров'я (IP3) юних спортсменів. Використовується комплекс морфологічних і функціональних показників, що мають найвищий ступінь взаємозв'язку з енергозабезпеченням організму, з рівнем загальної витривалості й гострої захворюваності і не передбачають застосування діагностичної апаратури [1]. Досліджуються показники фрізичного розвитку (зріст, маса тіла, життєва ємність легень (ЖЕЛ), кистьова динамометрія), а також стан серцевосудинної системи (ССС), який оцінюють після проведення тестової проби Руф'є.

Тестування здійснюють за допомогою таких індексів:

- Силовий індекс (Cl);

- Індекс Руфф'є (IP);

- Життєвий індекс (ЖІ);

- Індекс Робінсона «подвійний добуток» (ПД).
За допомогою таблиць оцінюють також відповідність маси тіла довжині тіла. Усі показники ранжовані. Їм присвоюють гендерну оцінку в балах. Після одержання кожного показника визначають загальну суму балів (індивідуальний індекс здоров'я), яка оцінює рівень фрізичного здоров'я: 5 балів і менше - низький, 6-10 - середній, 11-15 - високий.

Відповідно до результатів експрес-скринінгу соматичного здоров'я на момент констатуючого дослідження юних спортсменів основної групи розподіляють на три групи: здорові, «група ризику» (ГР), група «хворі» (ГХ). Спортсмени ГР и ГХ мають бути обстежені на наступних етапах скринінгу для визначення ендогенних чинників розвитку патологій (лімітуючих фрункцій) [27].

Для цього на mpeтьому emani скринінгу оцінюють параметри (функції), що відповідають рівню здоров'я спортсменів. Критеріями оцінки $\epsilon$ індекси, що вивчалися на другому еmani. Функцію фрізичного розвитку спортсменів оцінюють за авторськими гендерними таблицями відповідності маси тіла довжині тіла згідно з віком обстежених. Це дозволяє визначити індивідуальний ступінь зниження фуннціональних резервів провідних систем організму, конкретизувавши точки застосування реабілітаційних зусиль та їх спрямованість (загальнорозвивальна та загальнооздоровча, або корекційна). 
На четВертому етапі скринінгу використовують метод експрес-діагностики фрункціонального стану та резервних можливостей організму із застосуванням комп'ютерної програми «D\&K TEST» [16].

Аналізовані параметри: рівень функціонального стану й резервних можливостей організму; показник стану регуляторних систем організму.

Якісні характеристики аналізованих параметрів оцінюють згідно з кількісними показниками стану резервних можливостей організму: мінімальний - 1-9 балів; проміжний - 10-18; середній - 19-27; високий - 28-36; максимальний 37-45 балів.

Показники стану регуляторних систем: норма - 5 балів; стан фуннкціонального напруження - 4 бали; різко виражене напруження - 3 бали; стан перенапруження - 2 бали; стан виснаження (астенізації) - 1 бал.

На n'ятому emani скринінгу проводять дослідження функції зовнішнього дихання (ФЗД) у групі спортсменів, які за даними третього етаnу скринінгу мають граничні з нормою або низькі кількісні характеристики досліджуваного параметра. Даний вид дослідження дозволяє виявити механізми порушення ФЗД, що надає можливість обгрунтувати корекційну спрямованість фрізичних засобів і методів у програмах ФР, розроблених для даного контингенту спортсменів.

Нами запропоновано тест із форсованим видихом, який $\epsilon$ своєрідним функціональним навантаженням. Характеристики функціонального стану респіраторних шляхів юних спортсменів визначали за допомогою визначення форсованої життєвої ємності легенів (ФЖЄЛ), життєвої ємності вдиху (ЖЕЛ за першу секунду $\left(О Ф \mathrm{~B}_{1}\right)$, пікової об'ємної швидкості фрорсованого видиху (ПОШ), середньої об'ємної швидкості потоку повітря в інтервалі 25-75 \% ФЖЄЛ (СОШ 25-75). Дослідження слід проводити на апараті «Кардіо+» за допомогою каналу "Спіро». Обробку отриманих у ході вивчення графрічних характеристик кривої «потікоб'єм» проводять за допомогою комп'ютерної програми шляхом порівняння 3 певними величинами для даної вікової групи.

Результуючою складовою скринінгу $\epsilon$ «реабілітаційний діагноз». Він складається з кількох частин: лікарський висновок про допуск спортсмена до тренувальної діяльності; діагностована патологія (клінічний діагноз, форма (гостра, хронічна) і стадія перебігу хронічного процесу (ремісія, загострення)); ступінь адаптації спортсмена (задовільна адаптація; стадія напруження механізмів адаптації; незадовільна адаптація; зрив адаптації). Згідно з реабілітаційним діагнозом спортсменів розподіляють на групи для участі у програмах ФР.

Третій етап включає інтеграцію складових процесу ФР у практику підготовки спортсменів. Програми ФР завжди суворо індивідуальні й створюються з урахуванням анатомо-фрізіологічних особливостей, професійних характеристик юного спортсмена, але алгоритм їх створення $\epsilon$ більш-менш однотипним і формується, опираючись на базові принципи: вивчення суті (етіології й патогенезу), стадії і фоорми дисфрункціонального порушення в діяльності соматичних систем; дослідження ступеня відхилення параметра фуункцій, що становлять рівень соматичного здоров'я; вироблення стратегії й тактики процесу ФР; прогнозування результату реабілітації.

Стратегія ФР розробляється виходячи із цілей і завдань етапу підготовки спортсменів, яких реабілітують. Стратегія враховує такі цільові настанови:

1) функціональне розвантаження (щадіння порушеної фрункції) - превалює в процесі ФР спортсменів при гострих фоормах дисфункцій;

2) стимуляція саногенетичних процесів - $\epsilon$ провідною в процесі ФР спортсменів із хронічними формами соматичної патології, а також на етапі спортивної реабілітації (після перенесених у гострій формі соматичних захворювань) і в процесі ФР спортсменів, які мають провісники дисфонкцій;

3) стимуляція репаративних (функціональних) процесів - необхідна у процесі ФР спортсменів із хронічною формою дисфункцій, а також на етапі спортивного тренування спортсменів після захворювань, перенесених у гострій формі;

4) достатнє енергетичне й пластичне забезпечення саногенетичних механізмів - використовується протягом усього процесу ФР тематичних спортсменів;

5) динамічна корекція процесу ФР - використовується протягом усього курсу реабілітації й базується на даних контролю функціонального стану спортсменів;

6) контроль показників порушеної функції необхідний для зміни тактики процесу ФР (послідовне й раціональне виключення блоків ФР із тренувальної діяльності юних спортсменів).

Уніфікована схема побудови процесу фрізичної реабілітації наведена на рисунку 2.

Стратегія ФР будується згідно з моделлю, яка має компоненти константний та той, що трансрормується.

Константний компонент ідентичний для гомогенної групи спортсменів і декларує спря- 


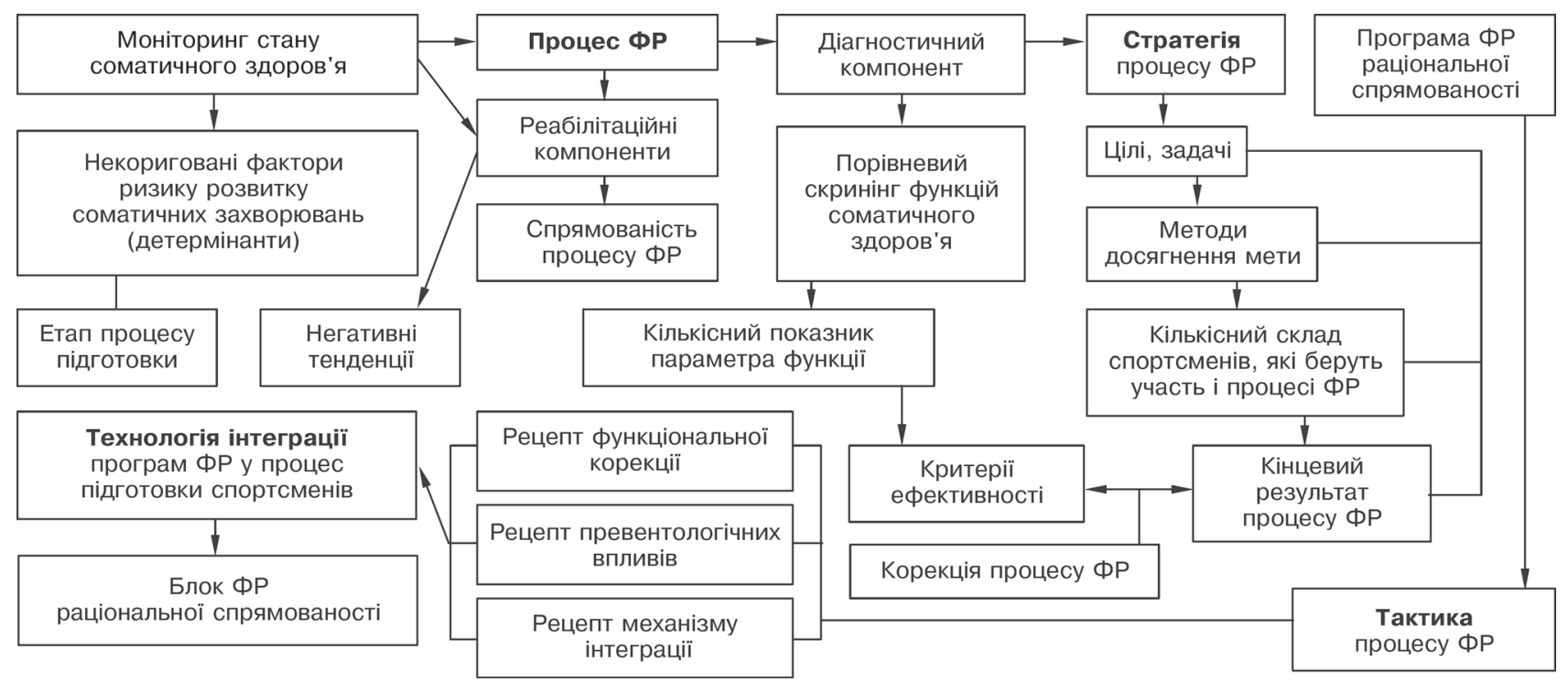

Рисунок 2 - Уніфікована схема побудови процесу фізичної реабілітації й технології інтеграції його структурних компонентів у процес підготовки тематичних спортсменів

ТАБЛИЦЯ 2 - Принцип диференціації компонента моделі програм фізичної реабілітації, що трансформується

\begin{tabular}{|c|c|c|}
\hline $\begin{array}{l}\text { Тип про- } \\
\text { грами }\end{array}$ & Реабілітаційний діагноз & $\begin{array}{l}\text { Різновид компонента моделі програми фізичної реабілітації, що } \\
\text { трансформується }\end{array}$ \\
\hline \multicolumn{3}{|c|}{ Превентивний напрямок (IІР3 - “середній») } \\
\hline I & $\begin{array}{l}\text { Здоровий (практично здоровий), задовільна } \\
\text { адаптація }\end{array}$ & $\begin{array}{l}\text { Тренувальна діяльність у повному обсязі, функціональна корекція } \\
\text { виявлених відхилень }\end{array}$ \\
\hline II & $\begin{array}{l}\text { Здоровий (практично здоровий), напруження } \\
\text { механізмів адаптації, (незадовільна адаптація) }\end{array}$ & $\begin{array}{l}\text { Часткове обмеження тренувальної діяльності, функціональна } \\
\text { корекція виявлених відхилень }\end{array}$ \\
\hline \multicolumn{3}{|c|}{ Постнозологічний напрямок (ÏР3 - «нижчий за середній», «низький») } \\
\hline III & $\begin{array}{l}\text { Практично здоровий, задовільна адаптація } \\
\text { (напруження механізмів адаптації) }\end{array}$ & $\begin{array}{l}\text { Тренувальна діяльність у повному обсязі, функціональна корекція } \\
\text { виявлених відхилень }\end{array}$ \\
\hline IV & $\begin{array}{l}\text { Хворий, напруження механізмів адаптації (не- } \\
\text { задовільна адаптація) }\end{array}$ & $\begin{array}{l}\text { Часткове обмеження тренувальної діяльності, функціональна } \\
\text { корекція процесу підготовки, з урахуванням виявлених відхилень }\end{array}$ \\
\hline v & Хворий, зрив адаптації & $\begin{array}{l}\text { Повне обмеження тренувальної діяльності, функціональна корек- } \\
\text { ція виявлених відхилень }\end{array}$ \\
\hline
\end{tabular}

мованість програми ФР (превентивна, постнозологічна). Для цього фахівці із ФР розподіляють обстежуваних на дві групи, згідно з індивідуальними показниками соматичного здоров'я: «група ризику» (ГР) (показник IP3 - «середній»); група «хворий» (ГХ) (IP3 - «нижчий за середній», «низький»). Спортсмени ГР беруть участь у програмах ФР превентивної спрямованості; ГХ - у програмах постнозологічної спрямованості. Подальша диференціація стратегії ФР здійснюється з урахуванням: віку етапу підготовки, статі обстежуваних на другому й третьому етапах - 3 урахуванням специфіки спеціалізації (наприклад, ігрового амплуа).

Компонент моделі, що трансфоормується, змінюється в межах реабілітаційного напрямку процесу ФР і залежить від фоорми участі спортсмена у тренувальній програмі (визначається за ступенем адаптації організму до фрізичних навантажень). Виходячи з можливих варіантів реабілітаційного діагнозу спортсмени розподіляються на групи, а програми ФР диференціюються на n'ять типів (I-V) (табл. 2).

Подальшу диференціацію стратегії процесу ФР здійснюють у комплексі моделі процесу ФР, що трансформується, і включає спеціальну й індивідуальну частини. У спеціальній частині використовують фрізичні засоби і методи спеціально-оздоровчої спрямованості. Обов'язковій корекції підлягають лімітуючі функції соматичного здоров'я спортсменів. Подальше наповнення i структура спеціальної частини обумовлені при- 
чиною, за якої спортсмен бере участь у процесі ФР (предметом корекції), на ній робиться акцент корекційних впливів.

3 урахуванням зазначеного здійснюють подальшу диференціацію програм ФР за різновидами у межах одного типу (табл. 3).

Далі фрахівець із ФР визначає ступінь потреби спортсмена в реабілітаційних заходах. Зазначена характеристика обумовлена величиною індивідуального відхилення функцій здоров'я від чинних вікових норм.

З урахуванням отриманих результатів обгрунтовуються структура індивідуальної частини програми ФР, дозування фізичних впливів у періодах ії реалізації, фрорма їх використання в тренувальному процесі, що розписується в індиВідуальному плані. У даному документі вказуються:

- особи, відповідальні за виконання завдань процесів навчання (спортсменів, тренерів, батьків), за реалізацію та контроль;

- планований термін реалізації періодів програми;

- змодельований результат кожного періоду реалізації програми.

Таким чином, запропонована модель програми максимально відтворює тактику процесу ФР, яка декларується в індивідуальному плані реабілітації спортсмена.
Тренери спортсменів, які відібрані для участі у ФР, дають висновок про відповідність індивідуальних планів реабілітації вимогам програм підготовки. Вони узгоджують з фахівцями із ФР форми проведення реабілітаційних занять (групові, індивідуальні, консультативні, самостійні тренувальні й позатренувальні). Запропонований нами комплексний підхід до процесу реалізації технології передбачає активну участь у ньому спортсменів і їхніх батьків. Протягом усього курсу реабілітації для них проводяться навчальні семінари. Широко використовується наочна демонстрація техніки виконання фрізичних вправ, відібраних для наповнення позатренувальних блоків ФР, пояснюються механізм їх впливу, засоби дозування й контролю над виконанням. Кратність навчальних занять варіабельна, визначається особами, відповідальними за практичну складову технології.

Таким чином, усі програми ФР, незважаючи на відмінності в спрямованості дій та в часовій регламентації своїх структурних компонентів, реалізуються у підготовчий, основний та стабілізаційний періоди, за активної участі спортсменів та їх батьків. Єдиними $€$ підходи організаторів до реалізації заходів процесу ФР (комплексний, диференційований) та спортсменів до виконання завдань процесу навчання (креативний та діяль-

ТАБЛИЦЯ 3 - Принцип диференціації спеціальної частини моделі програм фізичної реабілітації

\begin{tabular}{|c|c|c|}
\hline $\begin{array}{l}\text { Різновид } \\
\text { програми }\end{array}$ & Реабілітаційний діагноз & Різновид спеціальної частини - предмет функціональної корекції \\
\hline \multicolumn{3}{|c|}{ Превентивний напрямок (їР3 - «середній») } \\
\hline $\mathrm{I}-\mathrm{A}$ & Здоровий, адаптація задовільна & Лімітувальні функції соматичного здоров'я \\
\hline I-E & $\begin{array}{l}\text { Хронічна форма соматичної патології, адапта- } \\
\text { ція задовільна }\end{array}$ & Соматична система з діагностованою патологією \\
\hline II-A & $\begin{array}{l}\text { Хронічна форма соматичної патології, адапта- } \\
\text { ція незадовільна }\end{array}$ & $\begin{array}{l}\text { Механізми регуляції м'язової діяльності; соматична система з } \\
\text { діагностованою патологією }\end{array}$ \\
\hline II-Б & Здоровий, напруження механізмів адаптації & Метаболічні резерви м'язової діяльності \\
\hline \multicolumn{3}{|c|}{ Постнозологічний напрямок (IРР - «нижчий за середній», «низький») } \\
\hline III-A & Хронічна патологія, адаптація задовільна & Соматична система з діагностованою патологією \\
\hline III-Б & $\begin{array}{l}\text { Хронічна патологія, напруження механізмів } \\
\text { адаптації }\end{array}$ & $\begin{array}{l}\text { Метаболічні резерви м'язової діяльності соматична система з } \\
\text { діагностованою патологією }\end{array}$ \\
\hline IV-A & $\begin{array}{l}\text { Стан після перенесеної в гострій формі } \\
\text { соматичної патології, напруження механізмів } \\
\text { адаптації }\end{array}$ & $\begin{array}{l}\text { Соматична система з діагностованою патологією, метаболічні } \\
\text { резерви м'язової діяльності }\end{array}$ \\
\hline IV-5 & $\begin{array}{l}\text { Стан незадовільної адаптації на тлі хронічних } \\
\text { форм соматичної патології }\end{array}$ & $\begin{array}{l}\text { Механізми регуляції м'язової діяльності; соматична система з } \\
\text { діагностованою патологією }\end{array}$ \\
\hline IV-B & $\begin{array}{l}\text { Гостра (підгостра) форми соматичної патології } \\
\text { на тлі стану незадовільної адаптації }\end{array}$ & $\begin{array}{l}\text { Соматична система з діагностованою патологією; механізми } \\
\text { регуляції м'язової діяльності }\end{array}$ \\
\hline $\mathrm{v}$ & Хворий, зрив адаптації & $\begin{array}{l}\text { Механізми регуляції та метаболічні резерви м'язової діяльності; } \\
\text { соматична система з діагностованою патологією }\end{array}$ \\
\hline
\end{tabular}


ТАБЛИЦЯ 4 - Обгрунтування диференційованого підходу до реалізації програм фізичної реабілітації превентивної спрямованості

\begin{tabular}{|l|l|}
\hline \multicolumn{1}{|c|}{ Параметри } & \multicolumn{1}{|c|}{ Регламентовані параметри реалізації технології } \\
\hline Стать & $\begin{array}{l}\text { Обсяг та інтенсивність фізичного навантаження на тренувальних заняттях під час реабілітації; } \\
\text { тривалість фізіотерапевтичних процедур }\end{array}$ \\
\hline Вік & $\begin{array}{l}\text { Часова регламентація програми і її структурних компонентів; термін допуску до тренувальних } \\
\text { занять у повному обсязі; обсяг та інтенсивність фізичного навантаження на тренувальних за- } \\
\text { няттях під час реабілітації; режим рухової активності; кількість засобів і методів, що викорис- } \\
\text { товуються у схемі реабілітації }\end{array}$ \\
\hline Етап підготовки & $\begin{array}{l}\text { Регламентація часових і кількісних характеристик реалізації програми і їі структурних компо- } \\
\text { нентів; термін допуску до тренувальних занять під час реабілітації; режим рухової активності } \\
\text { під час курсу реабілітації; співвідношення у програмі різних інтеграційних форм; кількість спе- } \\
\text { ціальних вправ в одному занятті й кількість іх повторень; темп виконання спеціальних вправ }\end{array}$ \\
\hline $\begin{array}{l}\text { Нозологічна група хронічних } \\
\text { форм соматичної патології }\end{array}$ & $\begin{array}{l}\text { Етиологічний різновид блоків спеціальної спрямованості; різновид використовуваних у блоці } \\
\text { засобів і методів; кратність повторення курсів реабілітації протягом року }\end{array}$ \\
\hline Період реабілітації & $\begin{array}{l}\text { Відповідність засобів і методів цілям і завданням періоду реабілітації; форма інтеграції засобів } \\
\text { і методів ФР; тривалість занять спеціальними вправами; кількість спеціальних вправ в одному } \\
\text { занятті й кількість їх повторень; темп виконання спеціальних вправ }\end{array}$ \\
\hline Супутня патологія & Додаткові засоби і методи ФР із урахуванням супутньої патології \\
\hline
\end{tabular}

нісний), а також принципи практичної діяльності і принципи відбору спортсменів для участі в програмах ФР (рецептура умов). Єдиною є фрорма реалізації програми - схема тижневого мікроциклу та фрорма інтеграції - блок обгрунтованої спрямованості.

Диференційовані відмінності належать до обгрунтування спрямованості засобів та методів ФР для наповнення програми та фрорм інтеграції (за рецептурами). Різняться регламентація часових характеристик процесу ФР (програма, період, блок) та їх кількісна інтерпретація.

Диференціація процесу ФР відбувається згідно с положеннями, що наведені у таблиці 4.

Під час впровадження технології застосовують такі види контролю: попередній, оперативний, поточний, підсумковий, самоконтроль.

На четвертому етапі тричі оцінюють ефективність технології інтеграції програм ФР превентивної та постнозологічної спрямованості: безпосередньо після закінчення педагогічного експерименту (терміновий результат), наступні два рази - протягом року з інтервалом у шість місяців.

Після закінчення педагогічного експерименту оцінювали динаміку змін структури генеральної групи спортсменів згідно з такими параметрами скринінгових досліджень (критерії оцінки термінового результату): рівень соматичного здоров'я; ступінь адаптації організму до м'язової діяльності; лікарська оцінка соматичного здоров'я; аналіз закінчення хронічних фрорм соматичних захворювань у спортсменів.

Критеріями для оцінки віддаленого результату є: кількість випадків виявлення первинної со- матичної патології у спортсменів основної групи (аналіз диспансерних журналів і амбулаторних карт спортсменів); кількість рецидивів хронічних форм соматичної патології; кількість випадків зняття $з$ диспансерного обліку спортсменів із хронічними фрормами соматичної патології.

Обчислення результатів проводили на персональному комп'ютері із застосуванням стандартних пакетів програм для статистичної обробки даних наукових досліджень - Microsoft Excel 2000 i Statistica (версія 6.0).

Результати дослідження. Згідно з даними скринінгу соматичного здоров'я спортсменів основної групи диференціювали на декілька підгруп для участі у програмах превентивної спрямованості:

ГР (I-A) - 43 (45,74 \%) спортсмени, допущені до участі в тренувальному процесі 3 діагнозом «Здоровий» (20 спортсменів - групи попередньої підготовки (ГПП), 12 спортсменів - групи попередньої базової підготовки (ГПБП) та 11 спортсменів - групи спеціалізованої базової підготовки (ГСБП)). Вони мають «середній» показник індивідуального рівня здоров'я, адаптаційний потенціал на задовільному рівні, що дозволяло активно брати участь у тренувальному процесі та процесі ФР, стратегія якого спрямована на нормалізацію лімітуючих функцій.

ГР (І-Б) - 43 (45,74 \%) спортсмени з середнім рівнем соматичного здоров'я та задовільним ступенем адаптації організму до фрізичних навантажень, допущені до тренувальної діяльності 3 діагнозом «Практично здоровий» (хронічна формма патології, стадія компенсації). До гру- 
пи увійшли: 3 спортсмени ГПП, 17 спортсменів ГПБП, 23 спортсмени ГСБП. Стратегія процесу ФР - з урахуванням профрілю патології, спрямована на корекцію лімітуючих функцій.

ГР (II-A) - 6 спортсменів $(6,38 \%) 3$ діагностованими хронічними (підгострими) фрормами соматичної патології, наявність якої сприяла перенапруженню та виснаженню регулювальних систем організму на фроні достатніх метаболічних резервів, що призвело до зниження рівня їхнього фуннціонального стану та обмежувало участь у тренувальному процесі. До групи увійшли: 2 спортсмени ГПП, 3 спортсмени ГПБП, 1 спортсмен ГСБП. Стратегія процесу ФР - з урахуванням профрілю патології спрямована на корекцію відхилень параметрів соматичного здоров'я та адаптаційного потенціалу.

ГР (I/-Б) - 2 спортсмени (2,13 \%), які тренуються у ГСБП, котрі були визнані «здоровими», але у них було зареєстровано напруження механізмів адаптації, що виникло на фоні невідповідності рівня метаболічних можливостей організму вимогам тестувального навантаження, що обгрунтувало обмеження тренувальної діяльності під час курсу ФР та раціональну корекцію метаболічних резервів організму шляхом використання засобів та методів ФР.

Структура хронічних фрорм патології у спортсменів ГР (49 осіб $(100,00 \%)$ була така: ССС - 14 (28,57\%) спортсменів; сечовидільна - 2 (4,08 \%) спортсмени; респіраторна - 6 $(12,24 \%)$ спортсменів; травна - 10 (20,41\%) спортсменів; репродуктивна - 4 (8,16 \%) спортсменки; ОРА - 13 (26,53 \%) спортсменів. Це доводить етіологічну спрямованість превентивних програм ФР.

Для участі в програмах постнозологічної спрямованості спортсмени ГХ (101 особа) були розподілені на три підгрупи, згідно з фрормою їх участі в тренувальному процесі під час курсу ФР та організації подальшої реабілітаційної діяльності (різновид програми ФР):

ГX (III) - спортсмени, які мають достатні резервні можливості та у яких діагностовані хронічні соматичні захворювання без загострення - 49 осіб $(48,51 \%)$, фуннціональний стан - на рівні задовільної адаптації (40 (39,60 \%) спортсменів) та напруження механізмів адаптації (9 (8,91%) спортсменів). Стратегія процесу ФР: тренувальна діяльність у повному обсязі, корекція з урахуванням профрілю соматичної патології, розробка програм ФР, спрямованих на розширення резервних можливостей функцій, що забезпечують рівень здоров'я. Згідно зі ступенем адаптації спортсменів даної групи було розподілено на дві підгрупи (А та Б).
ГX (IV) - 46 (45,54 \%) спортсменів, яким рекомендовано часткове обмеження тренувальної діяльності під час курсу ФР (незадовільна адаптація, напруження адаптації на фроні недостатніх фрункціональних резервів). До групи увійшли: 30 $(29,70 \%)$ спортсменів, серед яких 11 (10,89\%) спортсменів - 3 гострою (підгострою) фрормою патології, 19 (18,81\%) - із загостренням хронічних форм захворювання. Стратегія процесу ФР: обґрунтована профрілем соматичної патології та величиною порушень основних характеристик адаптаційного потенціалу. Крім того, до цієї групи увійшли 16 (15,84\%) спортсменів з гострими (підгострими) формами дисфункцій різних соматичних систем, напруженням механізмів адаптації. Стратегія процесу ФР: часткове обмеження тренувальної діяльності та розроблення програм ФР з урахуванням профрілю патології та виявлених порушень основних характеристик адаптаційного потенціалу (відновлення метаболічних резервів). Спортсмени диференційовані на три підгруппи (A, $\mathrm{B}, \mathrm{B})$.

ГX (V) - спортсмени з дисфункціями функціональних систем (гостра фоорма), яким рекомендовано повне усунення від тренувальної діяльності - 6 осіб (5,94 \%): 1 спортсмен ГПП та 5 спортсменів ГСБП. Їхній функціональний стан свідчив про зрив адаптації. Різновид програм ФР: урахування профрілю соматичної патології, нормалізація основних характеристик адаптаційного потенціалу.

Спрямованість корекційної діяльності засобів та методів ФР обґрунтована нозологічною групою гострих та хронічних фрорм дисфрункцій: ССС - 24 випадки (гостра фрорма - 50,00\%, хронічна - 50,00 \%); сечовидільна система - 7 випадків (гостра фоорма - 42,86 \%; хронічна $57,14 \%)$; репродуктивна система - 4 випадки (хронічна фрорма - 100,00 \%); травна система 16 випадків (гостра фрорма - 25,00 \%; хронічна форма - 75,00 \%); респіраторна система - 33 випадки (гостра форма - 42,42 \%; хронічна $57,58 \%$ ); ОРА - 17 випадків (хронічна фрорма $100,00 \%$ ).

Після реалізації технології ФР за даними термінового оцінювання встановлено: диференційовано обґрунтована інтеграція комплексних засобів ФР в процесі підготовки спортсменів у $100 \%$ випадків призвела до достовірних змін рівня соматичного здоров'я обстежуваних ( $<<0,05)$, що позитивно відбилося на динаміці структури основної групи спортсменів під час оцінювання даного критерію ефективності. Зареєстровано зменшення питомої ваги спортсменів 3 недостатніми для ефективної тренувальної діяль- 
ТАБЛИЦЯ 5 - Оцінка ефективності реалізації технології за даними динаміки структури в генеральній групі спортсменів при лікарській оцінці стану здоров'я $(\mathrm{n}=260)$

\begin{tabular}{|c|c|c|c|c|}
\hline \multirow{4}{*}{ Етап дослідження } & \multicolumn{4}{|c|}{ Кількість спортсменів у групі з різним станом здоров'я, осіб (\% загальної кількості спортсменів) } \\
\hline & \multirow{3}{*}{ Здоровий } & \multicolumn{3}{|c|}{ Соматична патологія } \\
\hline & & \multirow{2}{*}{ Гостра форма } & \multicolumn{2}{|c|}{ Хронічна форма } \\
\hline & & & Ремісія & Загострення \\
\hline $\begin{array}{l}\text { До реалізації технології } \\
\text { Після реалізації технології }\end{array}$ & $\begin{array}{c}110(42,31) \\
155(59,62)^{\star}\end{array}$ & $33(12,69)$ & $\begin{array}{c}98(37,69) \\
105(40,38) \text { * }\end{array}$ & $19(7,31)$ \\
\hline
\end{tabular}

* Відмінності в групі спортсменів з однаковим станом здоров'я до й після реалізації технології, вірогідність відмінностей на рівні $(p<0,05)$.

ності показниками соматичного здоров'я - на $32,70 \%$, при неоднаковій позитивній динаміці показника в різних групах підготовки (ГПП - на $30 \%$; ГПБП - на 38,89 \%; ГСБП - на 28,89\%).

Ефективність диференційованої корекції причин ендогенного характеру підтверджена даними про відмінності ступеня чутливості спортсменів до реабілітаційних дій. Найбільш виражений реабілітаційний ефект в аспектах рівня соматичного здоров'я відмічено в ГХ: у спортсменок спостерігалась лінійна залежність між величиною приросту досліджуваного показника та етапом багаторічної підготовки (від 5,67 бала (m = 1,29 бала) в ГПП до 7,78 бала ( $m=0,83$ бала) в ГСБП) ( $<$ 0,05); у спортсменів - параболічна динаміка збільшення показника соматичного здоров'я від 3,73 бала ( $m=1,04$ бала) в ГПП до 5,83 бала ( $m=0,97$ бала) в ГСБП, з піком збільшення показника (7,27 бала ( $m=1,34$ бала)) в ГПБП (p < 0,05). В аспектах етапу підготовки найкращий реабілітаційний ефект відмічено у спортсменів ГСБП - максимальний приріст кількості здорових спортсменів (на 38,89 \%) при зниженні кількості спортсменів у групі ризику (на $10,00 \%)$.

Усунення в процесі реалізації технології ФР ендогенних та екзогенних коригованих фракторів ризику призвело до розширення адаптаційних резервів організму учасників програм ФР. Зареєстровано відсутність випадків діагностики станів незадовільної адаптації та її зриву; приріст питомої ваги спортсменів зі станом задовільної адаптації (на 14,23 \%) та напруженням регуляторних процесів (на 1,23%), це також підтверджено позитивною динамікою структури генеральної групи під час аналізу даних лікарських висновків про стан здоров'я. Зареєстровано відсутність випадків діагностики гострих станів та загострення хронічних процесів; зменшення загальної кількості юних спортсменів 3 діагностованими хронічними формами соматичної патології (з пе- реважним поліпшенням їхнього функціонального стану) (табл. 5).

Ефективність практичного впровадження технології підтверджена даними поточних медичних обстежень спортсменів протягом року. Відмічено зниження показника первинної захворюваності; відсутність випадків діагностики гострих фрорм функціонального походження; відсутність випадків загострення хронічних фрорм; зменшення питомої ваги спортсменів у диспансерній групі (з хронічними фрормами захворювань) на 32,38 \%.

Узагальнення отриманих даних свідчить про еорективність реалізації та виразну спрямованість розробленої технології на покращення показників соматичного здоров'я та резервних можливостей організму юних спортсменів, зниження показників соматичної захворюваності та позитивну динаміку її структури.

Дискусія. У результаті проведеного дослідження отримано три групи даних:

- що підтверджують та доповнюють існуюче положення про: зростання негативних тенденцій у стані соматичного здоров'я юних спортсменів у першій стадії багаторічної підготовки [13, 35, 38]; інтенсивну динаміку показників їхньої захворюваності в процесі спортивного становлення [23]; превалюючу питому вагу гострих патологічних станів, розвиток яких прямо або побічно опосередкований фракторами тренувальної діяльності юних спортсменів [10, 32, 36]; значну роль онтогенетичних особливостей у процесі розвитку патологічних порушень, особливо у критичні періоди онтогенезу $[6,11,36]$; лімітуючий вплив хронічних фрорм соматичної патології на ефективність процесу підготовки юних спортсменів $[8,19,21]$ в умовах інтенсифікації тренувальної діяльності [23, 25, 34];

- що розширюють та поглиблюють наукові знання про: причини розвитку гострих та прогресування хронічних форм соматичних захворювань у спортсменів віддаленого та найближ- 
чого резервів [7, 8, 19]; результати досліджень соматичного здоров'я та резервних можливостей організму юних спортсменів, показників їх захворюваності [24, 26, 34]; підходи до обгрунтування стратегії та реалізації тактики процесу ФР юних спортсменів при дисфрункціях соматичних систем $[14,31,33]$; принципи використання засобів і методів ФР в програмах підготовки спортсменів 3 діагностованими патологіями різних нозологічних групп [5, 14, 22].

У результаті дослідження обгрунтовано організаційно-методичні основи ФР юних спортсменів 3 дисоункціями соматичних систем організму та донозологічними формами даних станів, що дозволило розглянути ФР як безперервний процес превентивних і коригувальних технологій, раціонально інтегрованих у практику етапів першої стадії багаторічної підготовки спортсменів [27].

Уперше обгрунтовано і експериментально випробувано діагностичний комплекс - порівневий скринінг функціонального стану спортсменів [29]. У результаті отримано нові дані про лімітуючі фонкції організму юних спортсменів, які сприяють розвитку гострих і прогресуванню хронічних фоорм соматичних патологій [28]. Крім того, запропоновано механіз диференційованого використаня засобів і методів ФР за трьома рецептурами в рамках моделі програми ФР, які використовуються в тренувальному процесі за вперше запропонованими алгоритмами.

\section{Література}

1. Апанасенко Г. Л. Современные подходы к оценке состояния здоровья спортсмена и его коррекция / Г. Л. Апанасенко, Н. В. Морозов // Ліки України. - 2002. - № 9. - С. 49-51.

2. Балыкова Л. А. Метаболическая терапия в детской спортивной кардиологии / Л. А. Балыкова, С. А. Ивянский, А. Н. Урзяева // Дет. болезни сердца и сосудов. - 2011. - № 3. - С. 39-46.

3. Бокерия Л. А. Внезапная сердечная смерть у спортсменов: [обзор] / Л. А. Бокерия, О. Л. Бокерия, Т. Г. Ле // Анналы аритмологии. 2009. - № 2. - С. 24-29.

4. Быков А. Т. Влияние различных технологий выполнения спортивного массажа на биохимические показатели крови / А. Т. Быков, С. Н. Якименко, Л. С. Ходасевич, А. В. Полякова // Вопр. курортологии, физиотерапии и лечеб. физ. культуры. - 2011. - № 5. - С. 49-51.

5. Васильев О. С. Стоунтерапия, как эффективная и безопасная альтернатива электрофизиотерапии у юных спортсменов-диспластиков / О. С. Васильев // Спорт. медицина: наука и практика. - 2013. № 1 (10). - С. 63-64.

6. Гаврилов В. А. Иммунные показатели у футболистов 15-16 лет / В. А. Гаврилов, В. В. Макаровец, Е. Р. Линниченко, С. И. Ступченко // Заг. патологія і патол. фізіологія. - 2009. - № 4. - С. 210-214.

7. Граевская Н. Д. Спортивная медицина: курс лекций и практические занятия / Н. Д. Граевская, Т. И. Довлатова. - М.: Сов. спорт, 2005. - 299 с.

8. Гуревич Т. С. Недиагностированные пороки сердца у спортсменов высоких спортивных квалисрикаций / Т. С. Гуревич // Физкультура в профилактике, лечении и реабилитации. - 2009. - № 2. - С. 4-6.
Висновок. Проведене дослідження дозволило розробити ряд нових методичних положень, які передбачають широке розкриття можливостей фрізичної реабілітації у підвищенні рівня соматичного здоров'я юних спортсменів та оптимізації здоров'яформуючої складової процесу багаторічної підготовки спортсменів.

Перспектива подальших досліджень полягає у впровадженні запропонованої технології в процесі підготовки спортсменів віддаленого та найближчого резерву спорту вищих досягнень у ряді обласних міст України, для подальшого вдосконалення її̈ здоров'яфрормуючої складової.

Вдячності. Наукові дослідження виконувалися відповідно до Зведеного плану НДР у галузі фрізичної культури та спорту на 2011-2015 рр. за темою 4.4. «Удосконалення організаційних та методичних основ програмування процесу фрізичної реабілітації при дисфункціональних порушеннях у різних системах організму людини» (номер держреєстрації - 0111U001737). Також, згідно з планом наукової роботи НУФВСУ на 20162020 рр. згідно з темою кафедри фрізичної реабілітації 4.1. «Технологія фрізичної реабілітації при дисфункціях соматичних систем у процесі багаторічної підготовки спортсменів» (номер держреєстрації - 0116U001623).

Конфлікт інтересів. Автори заявляють, що не існує ніякого конфрлікту інтересів.

\section{References}

1. Апанасенко ГЛ, Морозов НВ. Современные подходы к оценке состояния здоровья спортсмена и его коррекция [Modern approaches to the evaluation of the health of the athlete and its correction]. Ліки України. 2002;9:49-51.

2. Балыкова ЛА, Ивянский СА, Урзяева АН. Метаболическая терапия в детской спортивной кардиологии [Metabolic therapy in pediatric sports cardiology]. Детские болезни сердца и сосудов. 2011;3:39-46.

3. Бокерия ЛА, Бокерия ОЛ, Ле ТГ. Внезапная сердечная смерть у спортсменов: [обзор][ Sudden cardiac death in athletes: [review]]. Анналы аритмологии. 2009;2:24-29.

4. Быков АТ, Якименко СН, Ходасевич ЛС, Полякова АВ. Влияние различных технологий выполнения спортивного массажа на биохимические показатели крови [Influence of various technologies of performance of sports massage on biochemical indices of blood]. Вопросы курортологии, физиотерапии и лечебой физической культуры. 2011;5:49-51.

5. Васильев ОС. Стоунтерапия, как эффективная и безопасная альтернатива электрофизиотерапии у юных спортсменов-диспластиков [Stone therapy as an effective and safe alternative to electrophysiotherapy in young dysplastic athletes]. Спортивная медицина: наука и практика. 2013;1 (10):63-4.

6. Гаврилов ВА, Макаровец ВВ, Линниченко ЕР, Ступченко СИ. Иммунные показатели у футболистов 15-16 лет [Immune indice in footballers aged 15-16 years]. Загальна патологія і патологічна фізіологія. 2009;4:210-4.

7. Граевская НД, Довлатова ТИ. Спортивная медицина: курс лекций и практические занятия [Sports medicine: a course of lectures and practical exercises]. Москва: Советский спорт; 2005: 299. 
9. Гурьянов М. С. Состояние здоровья и пути совершенствования медицинского обеспечения детско-юношеских спортивных школ : автореф. дис. ... канд. мед. наук: спец. 14.00.51 / М. С. Гурьянов. - Казань. 2002. $-22 \mathrm{c}$.

10. Долгова Т. И. Диагностика и восстановительное лечение хронического гастрита, ассоциированного Helicobacter pylori у спортсменов / Т. И. Долгова, В. П. Мудров // Физкультура в профилактике, лечении и реабилитации. - 2007. - № 2 (21) . - С. 14-18.

11. Дорохов Р. Н. Изменчивость соматических и функцииональных показателей у детей и подростков. / Р. Н. Дорохов // Дети, спорт, здоровье: межрегион. сб. науч. тр. по пробл. интеграт. и спорт. антропологии / Р. Н. Дорохов. - СГАФКСТ: Смоленск, 2011. - № 7. - С. 8-11.

12. Дубровская А. В. Оценка эфффективности применения физических методов профилактики и лечения травм и заболеваний опорнодвигательного аппарата у спортсменов: дисс. ... канд. мед. наук: спец. 14.00.51 / А. В. Дубровская. - М.: ФГУ РНЦВ. - 2009. - 130 с.

13. Жаріков О. В. Скринінгове обстеження молодих спортсменів для профілактики раптової смерті: пропозиції щодо спільного європейського протоколу / О. В. Жаріков // Медицина світу. - 2005. - № 8. C. 434-440.

14. Журавлева М. А. Физическая реабилитация спортсменов с заболеваниями органов пищеварения в процессе поэтапного обследования / М. А. Журавлева, И. Б. Исхаков, Ш. Б. Робиддинов // Спорт. медицина: наука и практика. - 2013. - № 1 (10) . - 112 с.

15. Закусило М. П. Нарушение менструальной функции у спортсменок подросткового возраста и методы ее коррекции / М. П. Закусило // Вісн. пробл. біології і медицини. - 2002. - № 6. - С. 89-91.

16. Карленко В. П. Способ экспресс-оценки функционального состояния и резервных возможностей организма-«D\&K-тест». Декларационный патент на изобретение № 2002108583 от 16.10.2003. Решение Гос. Деп-та интеллектуальной собственности МОН Украины о выдаче на изобретение. - Киев, 2005. - 19 с.

17. Кашуба В. А. Профилактика и реабилитация в современном спорте: проблемы и пути их решения. Методология, теория и практика в современной медицине, биологии, фармацевтике. ЦСРНИ: материалы междунар. науч.-.практ. конф. (Новосибирск, 1-2 окт. 2013) / В. А. Кашуба. - Новосибирск: ООО «Сибирпринт» . - 2013. - С. 47-56.

18. Кашуба В. А. Показатели соматического здоровья юных спортсменов как основа дифференцированного подхода к реализации программ ффизической реабилитации / В. А. Кашуба, С. С. Люгайло // Теория и методика физ. культуры. - 2015. - № 1. - С. 59-80.

19. Комолятова В. Н. Электрокардиографические особенности у юных элитных спортсменов / В. Н. Комолятова, Л. М. Макаров, В. О. Колосов, И. И. Киселева, Н. Н. Федина // Педиатрия. - 2013. - 92, № 3. C. $136-140$.

20. Корягин В. М. Здоровье спортсмена: теоретические предпосылки формирования здоровьесберегающего направления в процессе многолетней подготовки / В. М. Корягин // Теория и методика физ. культуры. - 2014. - № 4. - С. 10-24.

21. Криволап Н. В. Нетрадиционные методы реабилитации спортсменов с дисплазией соединительной ткани / Н. В. Криволап // Олимпийский спорт и спорт для всех: материалы XVIII Междунар. науч. конгр., Алматы, 2014. - № 3. - С. 321-324.

22. Кулемзина Т. В. Принципы немедикаментозной реабилитации у спортсменов. Олимпийский спорт и спорт для всех: материалы XVIII Междунар. науч. конгр., Алматы, 2014. - № 3. - С. 156-159.

23. Курникова М. В. Состояние морфоффункционального статуса высококвалифицированных спортсменов подросткового возраста: автореф. дис. ... канд. мед. наук: спец. 14.02.51 / М. В. Курникова. - М., 2009. - 22 c.

24. Кылосов А. А. Динамика воспалительной активности, вариабельности сердечного ритма и биохимических показателей в течение годичного цикла подготовки у юных спортсменов / А. А. Кылосов, А. А. Мельник, А. Ю. Мальцев и др. // Физиология человека. - 2009. № 4. - C. 82-96.

25. Лагода О. О. Новые подходы к диагностике функциональных и структурных нарушений опорно-двигательного аппарата у юных спорт-
8. Гуревич ТС. Недиагностированные пороки сердца у спортсменов высоких спортивных квалификаций [Undiagnosed heart defects in athletes of high sports qualifications]. Физкультура в профилактике, лечении и реабилитации. 2009;2:4-6.

9. Гурьянов МС. Состояние здоровья и пути совершенствования медицинского обеспечения детско-юношеских спортивных школ [State of health and ways to improve the medical support of children and youth sports schools [авторефрерат]. Казань; 2002. 22 c.

10. Долгова ТИ, Мудров ВП. Диагностика и восстановительное лечение хронического гастрита, ассоциированного Helicobacter pylori у спортсменов [Diagnosis and restorative treatment of chronic gastritis associated with Helicobacter pylori in athletes]. Физкультура в профилактике, лечении и реабилитации. 2007;2 (21):14-8.

11. Дорохов РН. Изменчивость соматических и функциональных показателей у детей и подростков [Variability of somatic and functional indices in children and adolescents]. Дети, спорт, здоровье: межрегион. сб. науч. трудов по проблеме интегративной и спортивной антропологии. СГАФКСТ: Смоленск, 2011; 7: 8-11.

12. Дубровская АВ. Оценка эффрективности применения физических методов профилактики и лечения травм и заболеваний опорно-двигательного аппарата у спортсменов [Assessment of the effectiveness of the application of physical methods for prevention and treatment of injuries and diseases of the locomotorium in athletes] [диссертация]. Москва; 2009:130 с.

13. Жаріков ОВ. Скринінгове обстеження молодих спортсменів для профрілактики раптової смерті: пропозиції щодо спільного європейського протоколу [Screening of young athletes for the prevention of sudden deaths: Proposals concerning mutual European protocol]. Медицина свіmy. 2005;8:434-40.

14. Журавлева МА, Исхаков ИБ, Робиддинов ШБ. Физическая реабилитация спортсменов с заболеваниями органов пищеварения в процессе поэтапного обследования [Physical rehabilitation of athletes with diseases of the digestive system in the process of stage-by-stage examination]. Спортивная медицина: наука и практика, 2013;1 (10): 112.

15. Закусило МП. Нарушение менструальной функции у спортсменок подросткового возраста и методы ее коррекции [Menstrual function disorder in teenagers and methods of its correction]. Вісн. проблем біології і медицини. 2002;6:89-91.

16. Карленко ВП, Душанин СА. Способ экспресс-оценки функционального состояния и резервных возможностей организма-«D\&Kтест» [The method of rapid assessment of the functional state and reserve capabilities of the body - «D \& K-test]. Декларационный патент на изобретение № 2002108583 от 16.10.2003.Решение Гос. Деп-та интеллектуальной собственности МОН Украины о выдаче на изобретение: Киев, 2005:19.

17. Кашуба ВА, Люгайло СС. Профрилактика и реабилитация в современном спорте: проблемы и пути их решения [Prevention and rehabilitation in modern sport: problems and ways to solve them]. Memoдология, теория и практика в современной медицине, биологии, фармацевтике. ЦСРНИ. Матер. междунар. науч.-.практ. конф., 1-2 октября 2013. Новосибирск: ООО «Сибирпринт»; 2013: 47-56.

18. Кашуба ВА, Люгайло СС. Показатели соматического здоровья юных спортсменов как основа дифференцированного подхода к реализации программ физической реабилитации [Indices of somatic health of young athletes as the basis for a differentiated approach to the implementation of physical rehabilitation programs]. Теория и методика физической культуры. 2015;1:59-80.

19. Комолятова ВН, Макаров ЛМ, Колосов ВО, Киселева ИИ, Федина НН. Электрокардиографические особенности у юных элитных спортсменов [Electrocardiographic features in young elite athletes]. Педuатрия. 2013;92, № 3:136-40.

20. Корягин ВМ. Здоровье спортсмена: теоретические предпосылки формирования здоровьесберегающего направления в процессе многолетней подготовки [Athlete's health: theoretical preconditions for the formation of a health-saving direction in the process of long-term preparation]. Теория и методика физической культуры. 2014;4:10-24. 
сменов / О. О. Лагода // Физ. культура: воспитание, образование тренировка. - 2001. - № 4. - С. 10-12.

26. Луцкан И. П. Состояние здоровья, качество жизни и научное обоснование совершенствования медико-социальной помощи детям, занимающимся спортом: автореф. дис. ... канд. мед. наук: спец. 14.02.03 / И. П. Луцкан. - М.: ФГВАОУ ВПО «СВФУ им. М. К. Амосова». 2012. $-23 \mathrm{C}$.

27. Люгайло С. С. Физическаческая реабилитация при дисфункциях соматических систем у спортсменов в процессе многолетней подготовки / С. С. Люгайло. - Луцк: Вежа - Друк. - 2016. - 244 с.

28. Люгайло С. С. Изучение критериев функций, составляющих показатели соматического здоровья юных спортсменов, - анализ факторов, лимитирующих рост профессионального становления занимающихся / С. С. Люгайло // Спорт. вісн. Придніпров'я. - 2015. - № 1. C. $147-157$.

29. Люгайло С. Результаты экспресс-оценки функционального состояния и резервных возможностей организма юных спортсменов: рациональная коррекция, стратегия и обоснование тактики процесса физической реабилитации / С. Люгайло // Молод. наук. вісн. Східноєвроп. нац. ун-ту ім. Лесі Українки. - 2015. - № 18. - С. 141-150.

30. Макаров Л. М. Динамика показателей реполяризации на нагрузке у спортсменов юношеских сборных команд РФ / Л. М. Макаров, В. Н. Комолятова, Н. Н. Федина // Спорт. медицина: наука и практика. 2013. - № 1 (10) - - С. 168.

31. Мелентьева Л. М. Физическая реабилитация юных спортсменов с нарушениями опорно-двигательного аппарата: автореф. дис. ... канд. мед. наук: спец. 14.00 .51 / Л. М. Мелентьева. - СПб.: СГМУ. 2007. -24 c.

32. Митусова М. А. Показатели фризической работоспособности юных спортсменов с нарушениями процессов реполяризации // Сб. тр. студентов и молодых ученых; РГУФКСМиТ. - М., 2012. - С. 202-205.

33. Орловская Ю. В. Профилактическо-реабилитационное направление в системе многолетней подготовки юных спортсменов / Ю. В. Орловская // Физкультура в профилактике, лечении и реабилитации. 2003. - № 2. - С. 9-14.

34. Поляков С. Д. Проблемы современного детского спорта и пути их решения / С. Д. Поляков, И. Е. Смирнов, И. Т. Корнеева, Е. С. Тертышная // Рос. педиатр. журн. - 2008. - № 1. - С. 53-56.

35. Пшебыльский В. Здоровьесбережение юного спортсмена на основе индивидуализации его многолетней подготовки. Спорт и здоровье: материалы II Междунар. конгр. - СПб. - 2005. - С. 232-233.

36. Скуратова Н. А. Характеристика показателей сердечно-сосудистой системы у детей-спортсменов / Н. А. Скуратова // Кардиология в Беларуси. - 2012. - № 2. - С. 58-67.

37. Смоленский А. В. Морфоффункциональные отличия юных гребцов с повышенным уровнем артериального давления / А. В. Смоленский, С. Ю. Золичева, А. В. Михайлова и др. // Физиология человека. 2010. - № 4. - C. 107-110.

38. Шеставина Н. В. Состояние здоровья юных спортсменов и медико-организационные мероприятия по снижению заболеваемости: автореф. дис. на соискание учен. степени канд. мед. наук / Н. В. Шеставина. - М., 1997. - 23 с.

39. Шинкарук О. А. Отбор спортсменов и ориентация их подготовки в процессе многолетнего совершенствования (на примере Олимпийских видов спорта): автореф. дис. ... доктора наук по физ. воспитанию и спорту: спец. 24.00.01 / О. А. Шинкарук // НУФВС Украины. - К., 2011. $41 \mathrm{c}$.
21. Криволап НВ. Нетрадиционные методы реабилитации спортсменов с дисплазией соединительной ткани [Nontraditional methods of rehabilitation of athletes with connective tissue dysplasia]. Олимпийский спорт и спорт для всех. Матер. XVIII междунар. науч. конгр., Алматы, 2014;3:321-4.

22. Кулемзина ТВ. Принципы немедикаментозной реабилитации у спортсменов [Principles of non-drug rehabilitation of athletes]. Олимпийский спорт и спорт для всех. Мат. XVIII междунар. науч. конгр., Алматы. 2014;3:156-9.

23. Курникова МВ. Состояние морфофункционального статуса высококвалифицированных спортсменов подросткового возраcma [State of morphofunctional status of highly skilled adolescent athletes] [автореферат]. Москва; 2009.22 c.

24. Кылосов АА., Мельник АА, Мальцев АЮ, [и др.]. Динамика воспалительной активности, вариабельности сердечного ритма и биохимических показателей в течение годичного цикла подготовки у юных спортсменов [Dynamics of inflammatory activity, heart rate variability and biochemical indices during anual training cycle for young athletes]. Физиология человека. 2009;4:82-96.

25. Лагода ОО. Новые подходы к диагностике функциональных и структурных нарушений опорно-двигательного аппарата у юных спортсменов [New approaches to the diagnosis of functional and structural disorders of the locomotorium in young athletes]. Физическая культура: воспитание, образование тренировка. 2001;4:10-2.

26. Луцкан ИП. Состояние здоровья, качество жизни и научное обоснование совершенствования медико-социальной помощи детям, занимающимся спортом [The state of health, quality of life and the scientific basis for improving medical and social assistance for children involved in sport] [авторесрерат]. Москва; 2012.23 c.

27. Люгайло СС. Физическаческая реабилитация при дисфункциях соматических систем у спортсменов в процессе многолетней подготовки [Physical rehabilitation during dysfunctions of somatic systems in athletes in the process of long-term preparation]. Луцк: Вежа - Друк, 2016:244.

28. Люгайло СС. Изучение критериев функций, составляющих показатели соматического здоровья юных спортсменов, - анализ факторов, лимитирующих рост профессионального становления занимающихся [A study of the function criteria that constitute the indices of the somatic health of young athletes is an analysis of the factors limiting the growth of the professional development of those engaged]. Спорт. вісн. Придніпров'я. 2015;1:147-57.

29. Люгайло С. Результаты экспресс-оценки функционального состояния и резервных возможностей организма юных спортсменов: рациональная коррекция, стратегия и обоснование тактики процесса физической реабилитации [The results of rapid assessment of the functional state and reserve capabilities of young athletes: rational correction, strategy and rationale for the tactics of the physical rehabilitation process]. Молодіжний науковий вісник Східноєвропейського національного університету імені Лесі Українки. 2015;18:141-50.

30. Макаров ЛМ, Комолятова ВН, Федина НН. Динамика показателей реполяризации на нагрузке у спортсменов юношеских сборных команд РФ [Dynamics of repolarization indices on the load among athletes of junior national teams of the Russian Federation]. Спортивная медицина: наука и практика. 2013;1 (10):168.

31. Мелентьева ЛМ. Физическая реабилитация юных спортсменов с нарушениями опорно-двигательного аппарата [Physical rehabilitation of young athletes with disorders of the musculoskeletal system] [автореферат]. Санк-Петербург; 2007.24 c.

32. Митусова МА. Показатели физической работоспособности юных спортсменов с нарушениями процессов реполяризации [Indices of physical performance of young athletes with repolarization process disorders]. Сб. тр. студентов и молодых ученых; РГУФКСМит: Москва, 2012:202-5.

33. Орловская ЮВ. Профиллактическо-реабилитационное направление в системе многолетней подготовки юных спортсменов [Prophylactic and rehabilitation direction in the system of long-term training of young athletes]. Физкультура в профилактике, лечении и реабилитации. 2003:2:9-14. 
34. Поляков СД, Смирнов ИЕ, Корнеева ИТ, Тертышная ЕС. Проблемы современного детского спорта и пути их решения [Problems of modern children's sport and ways of their solution]. Российский педиатрический журнал. 2008;1:53-6.

35. Пшебыльский В. Здоровьесбережение юного спортсмена на основе индивидуализации его многолетней подготовки [The health of a young athlete on the basis of individualization of his long-term training]. Спорт и здоровье. Мат. II Междунар. конгр. Санк-Петербург; 2005:232-3.

36. Скуратова НА. Характеристика показателей сердечно-сосудистой системы у детей-спортсменов [Characteristics of cardiovascular system indices in children-athletes]. Кардиология в Беларуси. 2012;2:58-67.

37. Смоленский АВ, Золичева СЮ, Михайлова АВ, [и др.]. Морфофункциональные отличия юных гребцов с повышенным уровнем артериального давления [Morphofunctional differences of young rowers with an increased level of arterial pressure] . Физиология человека. 2010;4:107-10.

38. Шеставина НВ. Состояние здоровья юных спортсменов и медико-организационные мероприятия по снижению заболеваемости [The state of health of young athletes and medical and organizational measures to reduce the incidence of disease][авторефрерат]. Москва; $1997.23 \mathrm{c}$.

39. Шинкарук ОА. Отбор спортсменов и ориентация их подготовки в процессе многолетнего совершенствования (на примере Олимпийских видов спорта) [Selection of athletes and the orientation of their training in the process of long-term improvement (on the example of the Olympic sports)] [автореферат]. Киев; 2011.41 c. 